\title{
Analysis of Land Use/Cover Dynamics in a Rapidly Urbanizing City: The Case of Gombe Metropolitan Area, Nigeria
}

\author{
Bulus L. Gadiga ${ }^{1}$, Mala Galtima ${ }^{2}$ \\ ${ }^{1}$ Department of Geography, Adamawa State University, Mubi, Nigeria \\ ${ }^{2}$ Department of Geography, Modibbo Adama University of Technology, Yola, Nigeria \\ Email: bulgami@gmail.com, bulga_mi@yahoo.com,galtimam@gmail.com
}

How to cite this paper: Gadiga, B.L. and Galtima, M. (2017) Analysis of Land Use/Cover Dynamics in a Rapidly Urbanizing City: The Case of Gombe Metropolitan Area, Nigeria. Journal of Geographic Information System, 9, 637-647. https://doi.org/10.4236/jgis.2017.96040

Received: September 15, 2017 Accepted: November 20, 2017 Published: November 23, 2017

Copyright ( 92017 by authors and Scientific Research Publishing Inc. This work is licensed under the Creative Commons Attribution International License (CC BY 4.0).

http://creativecommons.org/licenses/by/4.0/

\begin{abstract}
The study examines the dynamics of land use/cover in a rapidly urbanizing city of Gombe in Northeast Nigeria. The objective was to apply geospatial techniques in mapping and characterization of the pattern of land use changes in the metropolis that occurred between 1984 and 2015, and assess its' implications on the socio-economic development of the city. The Landsat satellite images of the area were acquired and classified using maximum likelihood algorithm in identifying the historical trend in the land use changes. The application of Multi-Layer Perception (MLP) neutral network in the prediction of land use changes in the area reveals that Gombe metropolis has witnessed a phenomenal growth in size (133\%) between 1991 and 2003. This growth was largely brought by changes in political status of the city that reflected in the socio-economic functions it performs. A 10-year trend in the growth forecast (2015-2055) reveals lack of abatement in the rapidity of this growth pattern. The consequences of this growth include the aggravation of the existing slumps, problems of infrastructure and housing among others. It is recommended that zonal-based planning approach be adopted within the framework of a master plan to tackle the existing and future development needs of the city. The implications of the findings are further discussed.
\end{abstract}

\section{Keywords}

Geospatial, Land Cover, Landsat, Multi-Layer Perception, Urbanization

\section{Introduction}

In Nigeria urbanization predates the European influence with the emergence of 
cities like Benin, Ibadan, Kano and a few others that served as commercial and capitals of city states and kingdoms. However, greater impetus to urbanization was aggravated by the colonial and independent Nigerian urban development policies that were dominated by political and socio-economic factors. Urbanization is the growth of an urban area which entails spread-out of development that consumes significant amounts of natural and man-made resources. During the colonial era, new administrative centers were established based on their economic interest which became centers of attraction and grew to become towns. The economic interest of the colonial government explains the pattern of urbanization and urban development in the colonial era. The major factor of urbanization in the post colonial era after independence was the creation of state capitals in newly created states. Nigeria's urban population has grown from less than 7 percent urban in 1931 to 42 percent in 1991 and it is projected to reach 61.6 percent in 2025 [1]. Between 1952 and 1982, many Nigerian towns and cities have had more than 1000 percent growth in their population [1]. This has resulted in unprecedented levels of urban expansion such that in 2014 it has been estimated [2] at more than $6.5 \%$ per annum. These developments have rapidly impacted on urban land use/cover changes. Urban land use changes through expansion results in the increase in impervious surfaces which causes flooding and runoff that pollutes waterways. Development as a result of urbanization not only decreases the quality and amount of forest areas, farmlands, woodlots and open spaces but also breaks up the ecosystems into smaller chunks that disrupt ecological functions and fragment habitats. Apart from environmental impact, urbanization has implications in host of economic and social issues relating to deterioration of urban communities and the quality of life in the suburbia [3] [4].

According to [3], apart from environmental impacts, urbanization has implications on economic and social issues relating to urban communities and the quality of life. Many Nigerian urban areas were unprepared for the changes brought by the rapid urbanization, especially in housing and infrastructure supplies, which led to uncontrollable urban expansion [5] [6]. Thus posing a serious challenge to all stakeholders in monitoring and the regulation of land use/cover and associated developments [7] [8]. This work, therefore, aims at examining the changing pattern of land use/cover and its socio-economic implications in Gombe metropolitan area between 1984 and 2055.

\section{The Study Area}

Gombe metropolis is the capital of Gombe state and located in the Northeastern part of Nigeria on latitude $10^{\circ} 14 / \mathrm{N}$ and $10^{\circ} 20 / \mathrm{N}$ of the equator, and longitude $11^{\circ} 07 \mathrm{~N}$ and $11^{\circ} 13 / \mathrm{E}$ of Greenwich Meridian, see Figure 1. According to the National census of 2006, Gombe metropolis has a population of 195,298 (NPC, 2006) and at present it is projected to have about 360,000 people. The metropolis lies in the Sudan savannah and enjoys a sub-tropical climate with distinctive wet and dry seasons having average annual rainfall of about $933 \mathrm{~mm}$ and characterized 


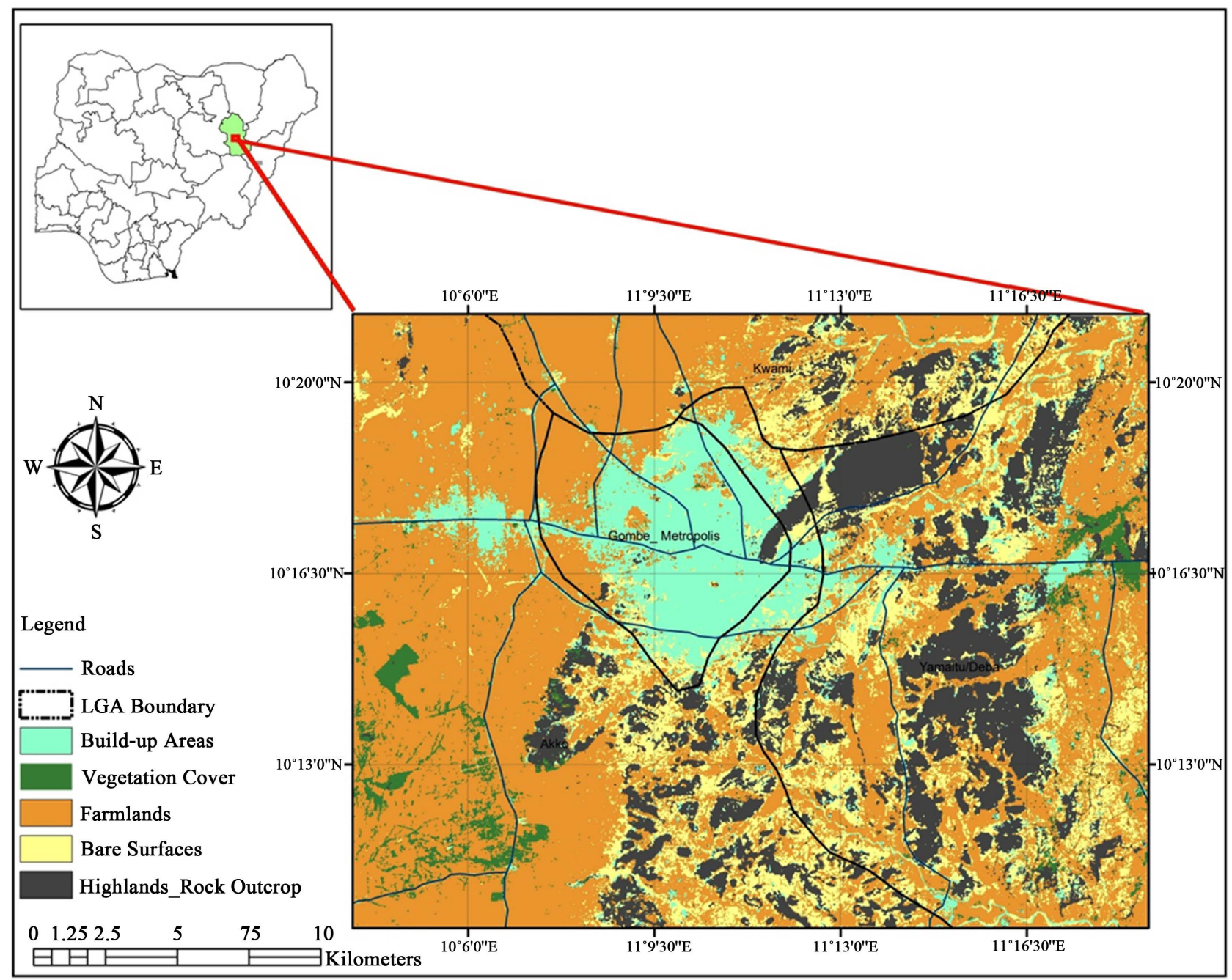

Figure 1. Map of the study area (Source: Authors production).

by a long dry season of between 6 and 7 months. It experiences a minimum temperature of about $18^{\circ} \mathrm{C}$ during the months of November/December and a maximum temperature of $37^{\circ} \mathrm{C}$ around March and April. Relative humidity of 97\% is observed in August and drop to less than 10\% during the dry harmattan period between December and January [9]. The people are predominantly reliant on agricultural production and trade in semi-processed and manufactured goods.

\section{Methodology}

The datasets used in this study were mainly derived from Landsat imageries acquired in 1984, 1991, 2003 and 2015. Theses imageries were sourced from one of the USGS websites; (https://glovis.usgs.gov/). The images selected were those acquired during the hamattan season (November-January) this was partly to reduce radiometric errors due to seasonal variations. The characteristics of the images are shown in Table 1. The Geo-information software used includes; IDRISI version 18 and ArcGIS, 10.0. The IDRISI Terrset was used in the image 
Table 1. Landsat images characteristics.

\begin{tabular}{|c|c|c|c|}
\hline \multirow{2}{*}{\multicolumn{2}{|c|}{ LANDSAT-5 (TM), 7 (ETM+) }} & \multicolumn{2}{|l|}{ Landsat-8 OLI } \\
\hline & & \multirow{2}{*}{$\frac{30 \mathrm{~m} \text { Coastal/Aerosol } 0.435-0.451}{30 \mathrm{~m} \text { Blue } 0.452-0.512}$} & \multirow{2}{*}{$\begin{array}{l}\text { Band } 1 \\
\text { Band } 2\end{array}$} \\
\hline Band 1 & $30 \mathrm{~m}$ Blue $0.441-0.514$ & & \\
\hline Band 2 & $30 \mathrm{~m}$ Green 0.519 - 0.601 & $30 \mathrm{~m}$ Green $0.533-0.590$ & Band 3 \\
\hline Band3 & $30 \mathrm{~m}$ Red $0.631-0.692$ & $30 \mathrm{~m}$ Red $0.636-0.673$ & Band 4 \\
\hline Band 4 & $30 \mathrm{~m}$ Near IR $0.772-0.898$ & $30 \mathrm{~m}$ Near IR $0.851-0.879$ & Band 5 \\
\hline Band 5 & 30 m SWIR-1 1.547 - 1.749 & $30 \mathrm{~m}$ SWIR 1.566 - 1.651 & Band 6 \\
\hline \multirow{2}{*}{ Band 6} & $120 \mathrm{~m}(\mathrm{TM}) 10.31-12.36$ & 100 m TIR-1 $10.60-11.19$ & Band 10 \\
\hline & $60 \mathrm{~m}(\mathrm{ETM}+) \mathrm{TIR}$ & $100 \mathrm{~m}$ TIR-2 $11.50-12.51$ & Band 11 \\
\hline Band 7 & 30 m SWIR-2 2.064 - 2.345 & 30 m SWIR-2 2.107 - 2.294 & Band 7 \\
\hline \multirow[t]{2}{*}{ Band 8} & $15 \mathrm{~m}$ Pan 0.515- 0.896 & $15 \mathrm{~m}$ Pan $0.503-0.676$ & Band 8 \\
\hline & & $30 \mathrm{~m}$ Cirrus $1.363-1.384$ & Band 9 \\
\hline
\end{tabular}

*(Landsat TM has no panchromatic band).

processing and analysis, while the ArcGIS was used for visualization of the processed images.

Area of Interest (AOI) was extracted from the four (4) Landsat scenes using the "Window" tool in IDRISI. False Colour Composite (RGB) of the three bands for each of the selected dates was made in order to increase the pictorial quality for easy visual interpretation and identification of features on the images. The images were further subjected to geometric correction using the "Resampling" technique. This is carried out in order to co-register the images as suggested [10] [11]. The images were classified using the Maximum Likelihood algorithm into five classes (Built-up Areas, Vegetation, Farmlands, Bare surfaces and Highlands/ Rock out-crops).

In order to make prediction of future changes in urban growth of Gombe metropolis, Land Change Modeler (LCM) in the IDRISI environment was used. LCM is a land change modeler used in pair wise comparison of qualitative data. Its development came as a result of the combination of different models and sub-models. The classified images of 2003 and 2015 were used for the prediction as required by the software. The LCM uses two types of methods to model transition potentials of change areas; i.e. Multi-layer Perception (MLP) neural network and Logistic regression. However, for this study, MLP neural network was used for modeling the transition potentials of changes because it has been extensively enhanced to give a good quality of result. Markov Chain analysis was used by the LCM to model future urban growth in Gombe metropolis for the periods of 2025, 2035, 2045 and 2055.

\section{Results and Discussions}

\subsection{Urbanization in Gombe Metropolis}

The classification results for the images show that Gombe metropolis has experienced spatial growth. In 1984 the spatial extent of the metropolis was estimated at 1104.03 hectares. And between 1984 and 1991 the growth trend shows a 62\% 
increase in built-up areas, which stood at 1792.44 hectares. Gombe metropolis further expanded especially following its' designation as the capital city of the newly created Gombe state in 1996 (see Table 2). The built-up areas experienced explosive growth in size by more than 133\% (2385.27 hectares), between 1991 and 2003. The new status of the metropolis came with the establishment of government ministries and extra-ministerial departments and agencies, added commercial functions and the influx of new jobs, which all attracted scores of people from the neighboring settlements. This led to further increase in built-up areas of the metropolis by $62 \%$ between 2003 and 2015. Although the percentage increase has reduced from $133 \%$ to $61 \%$, nevertheless the built-up areas have experienced growth of 2582.02 hectares.

The other land uses were also affected by the growth pattern. The classification results show that vegetation in the area has shown a consistent decrease in relation to built-up areas while the remaining land uses (Farmlands, bare surfaces and highlands/rock outcrops) show irregular patterns (see Table 2 and Table 3 ). Figures 2-5 shows the pictorial representation of the pattern of land use changes in the study area.

Table 2. Aerial extent of land cover (in hectare).

\begin{tabular}{ccccc}
\hline Land Cover & 1984 & 1991 & $\mathbf{2 0 0 3}$ & $\mathbf{2 0 1 5}$ \\
\hline Build-Up Areas & 1104.03 & 1792.44 & 4177.71 & 6759.72 \\
Vegetation Cover & $11,248.1$ & 6730.47 & 2381.94 & 1696.14 \\
Farmlands & $33,603.5$ & 34,379 & $35,329.5$ & $31,175.6$ \\
Bare Surfaces & 1503.27 & $12,566.8$ & 5609.7 & 9228.6 \\
Highlands/Rock Outcrop & $10,712.4$ & 2702.61 & $10,672.5$ & 9311.22 \\
\hline
\end{tabular}
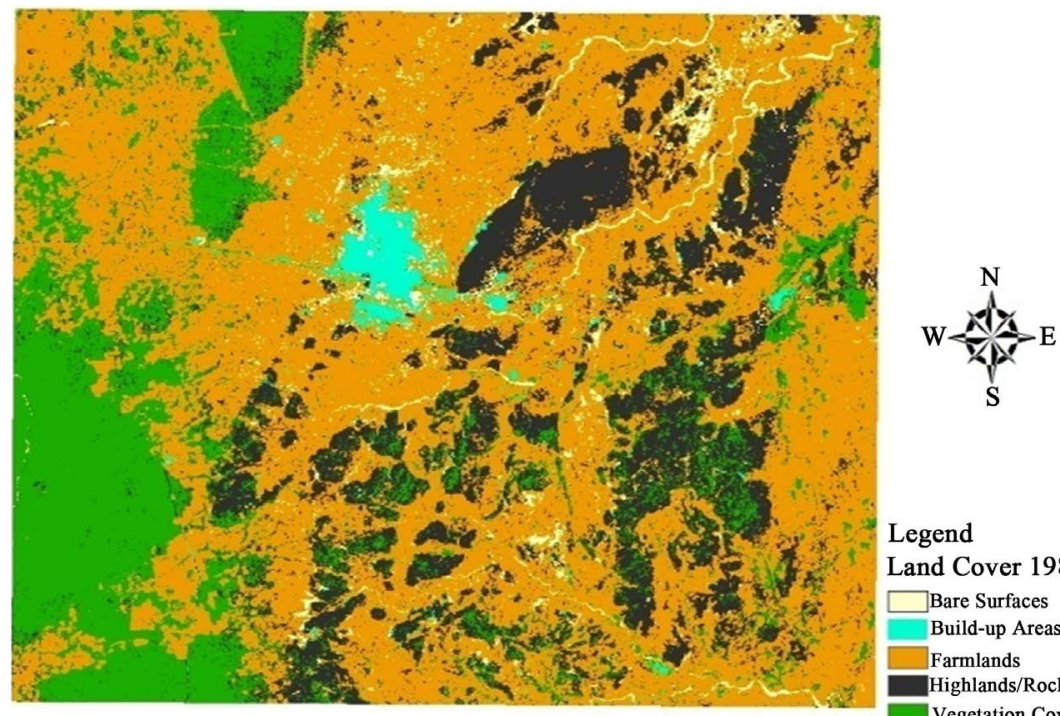

Legend

Land Cover 1984

$\square$ Bare Surfaces

Build-up Areas

$\square$ Farmlands

Highlands/Rock Outcrop

Vegetation Cover

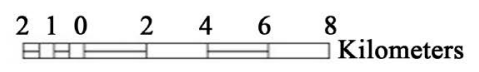

Figure 2. Land cover map of 1984. 


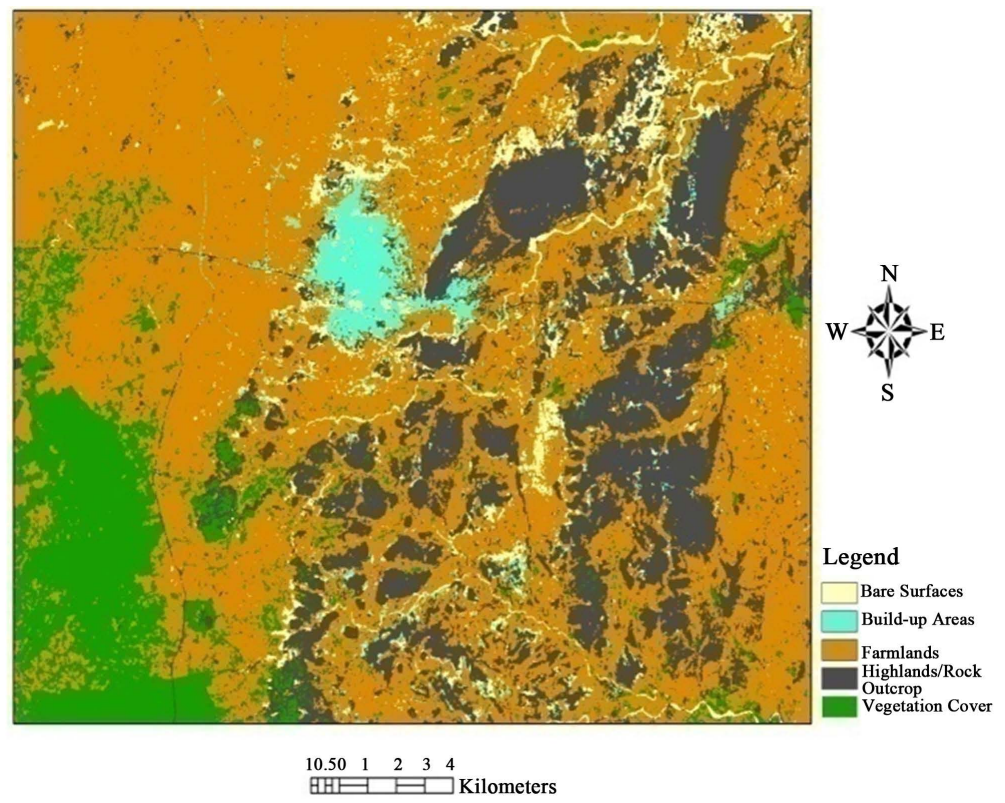

Figure 3. Land cover map of 1991.

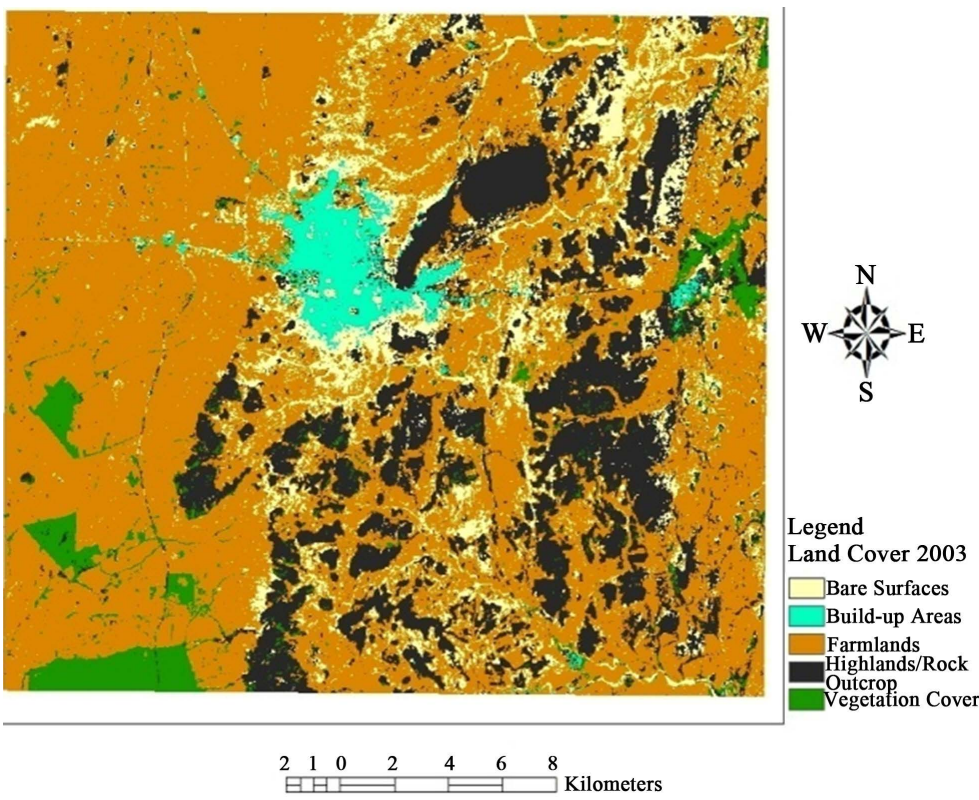

Figure 4. Land cover map of 2003.

Table 3. Post classification change analysis.

\begin{tabular}{ccccccc}
\hline Land Cover & $1984 / 1991$ & \% Change & $1991 / 2003$ & \% Change & $2003 / 2015$ & \% Change \\
\hline Build-Up Areas & 688.41 & 62.35 & 2385.27 & 133.07 & 2582.01 & 61.804 \\
Vegetation Cover & -4517.63 & -40.16 & -4348.53 & -64.61 & -685.8 & -28.79 \\
Farmlands & 775.5 & 2.31 & 950.5 & 2.76 & -4153.9 & -11.76 \\
Bare Surfaces & $11,063.53$ & 735.96 & -6957.1 & -55.36 & 3618.9 & 64.51 \\
$\begin{array}{c}\text { Highlands/Rock } \\
\text { Outcrop }\end{array}$ & -8009.79 & -74.77 & 7969.89 & 294.90 & -1361.28 & -12.76 \\
\hline
\end{tabular}




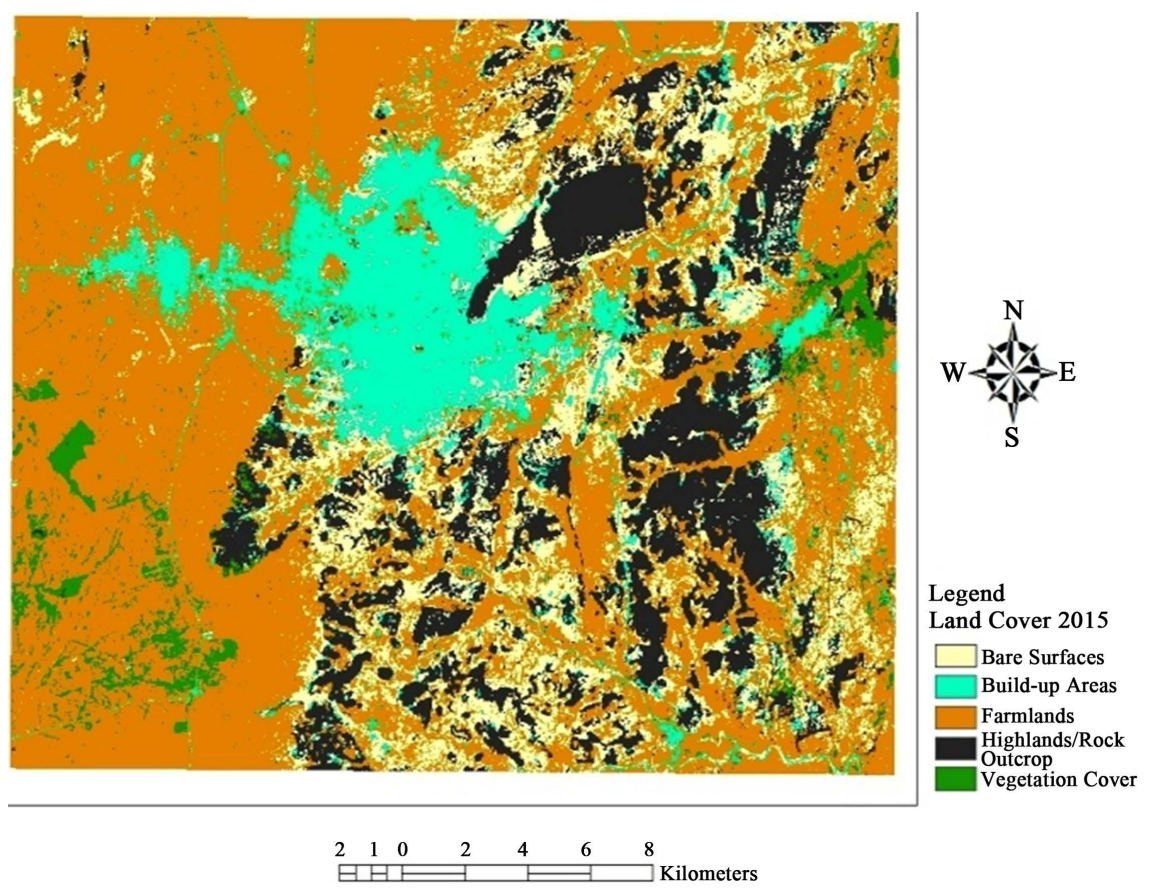

Figure 5. Land cover map of 2015.

The reduction in vegetation cover have serious implications on the ecological system as habitats are fragmented thereby affecting the biodiversity of the area. Increases in impervious surfaces as a result of urbanization are also expected to increase the rate of runoff, which also contributes to frequent flooding and waterways pollution. Furthermore, the undulating nature of Gombe metropolis has made it ideal for accelerated soil erosion in the absence of rapidly dwindling vegetation cover. This results in socio-economic consequences of farmlands loss due to the threats by soil erosion and thus putting to jeopardy the survival of the teeming population who depend on the marginal urban lands.

\subsection{Prediction of Urban Growth in Gombe Metropolis}

The results obtained from the land use classifications (2003 to 2015) were used for the prediction of change in urban growth in Gombe metropolis. The prediction reveals that Gombe metropolis will be increasing but at a declining pace (see Table 4 and Table 5). This pattern of decrease in growth rate overtime is attributed to the lack of inclusion of future road development that will link up inaccessible built areas of the city and the areal restrictions imposed by highlands in the modeling processes. Static elevation and road layers were used in modeling the future changes. The prediction analysis shows that the areal extent of the built-up areas will be 10,546.7, 13,167.5, 14,946.6 and 16,138.3 hectares in 2025, 2035, 2045, and 2055 respectively. This shows that the metropolis will increase by $56 \%$ between 2015 and 2025 with total area coverage of 3786.98 hectares. The built-up areas will be expected to increase by approximately $25 \%$ (2620.80 hectares) between 2025 and 2035. It is also expected to further increase by 13.5 and $8 \%$ between 2035 and 2045, and 2045 and 2055 respectively. The Figures 6-9, 


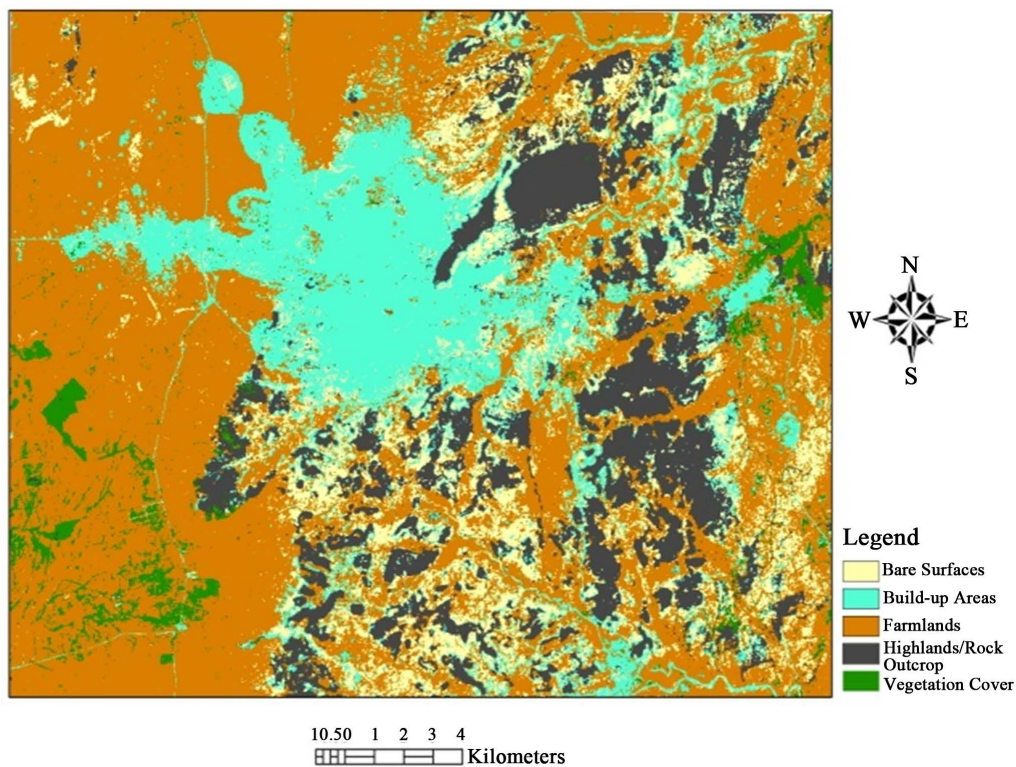

Figure 6. Land cover map of 2025.

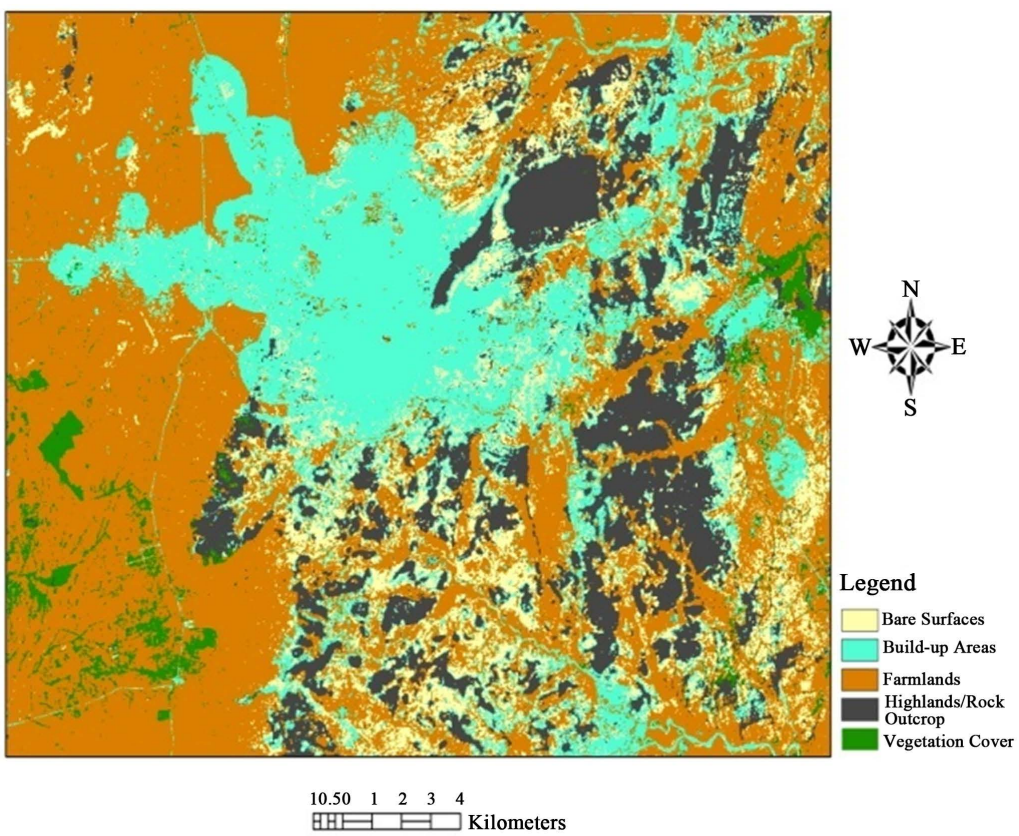

Figure 7. Land cover map of 2035.

Table 4. Predicted land cover areal extent (in hectares).

\begin{tabular}{ccccc}
\hline Land Cover & 2025 & 2035 & 2045 & 2055 \\
\hline Build-Up Areas & $10,546.7$ & $13,167.5$ & $14,946.6$ & $16,138.3$ \\
Vegetation Cover & 1682.46 & 1633.5 & 1563.3 & 1494.99 \\
Farmlands & $29,800.6$ & $28,242.7$ & $26,963.4$ & 26,024 \\
Bare Surfaces & 7416.54 & 6860.7 & 6762.96 & 6811.29 \\
Highlands/Rock Outcrop & 8724.96 & 8266.86 & 7935.12 & 7702.83 \\
\hline
\end{tabular}




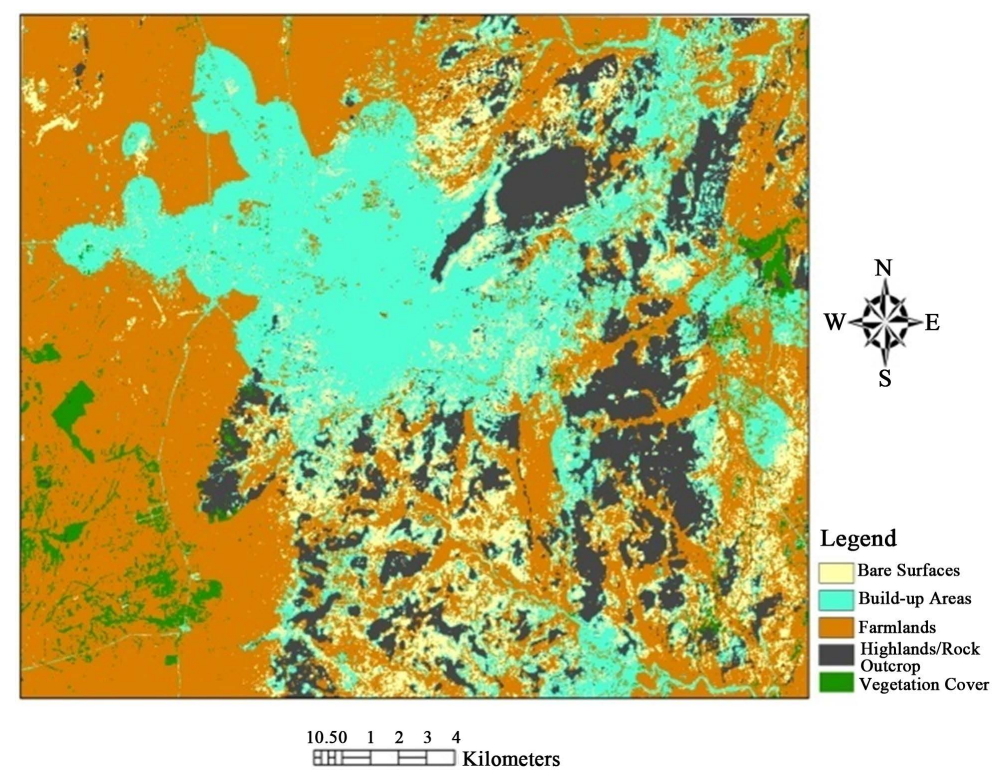

Figure 8. Land cover map of 2045.

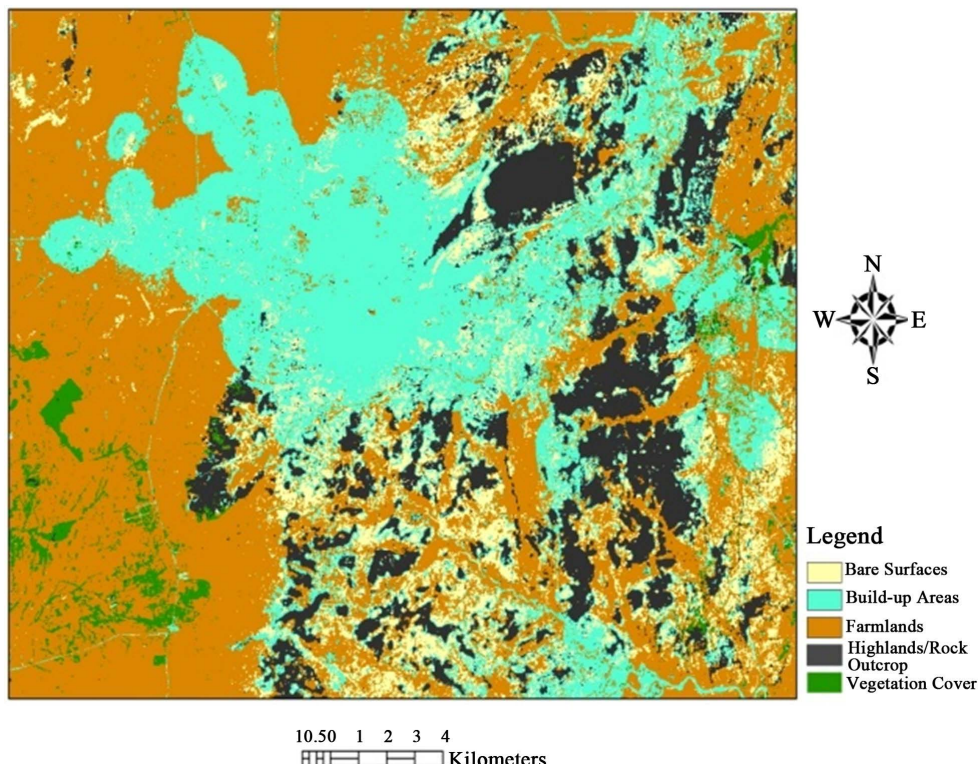

Figure 9. Land cover map of 2055.

Table 5. Post classification change analysis.

\begin{tabular}{|c|c|c|c|c|c|c|c|c|}
\hline Land Cover & $2015 / 2025$ & $\begin{array}{c}\% \\
\text { Change }\end{array}$ & $2025 / 2035$ & $\begin{array}{c}\% \\
\text { Change }\end{array}$ & $2035 / 2045$ & $\begin{array}{c}\% \\
\text { Change }\end{array}$ & $2045 / 2055$ & $\begin{array}{c}\% \\
\text { Change }\end{array}$ \\
\hline Build-Up Areas & 3786.98 & 56.02 & 2620.80 & 24.85 & 1779.10 & 13.51 & 1191.70 & 7.97 \\
\hline $\begin{array}{l}\text { Vegetation } \\
\text { Cover }\end{array}$ & -13.68 & -0.81 & -48.96 & -2.91 & -70.20 & -4.30 & -68.31 & -4.37 \\
\hline Farmlands & -1375.00 & -4.41 & -1557.90 & -5.23 & -1279.30 & -4.53 & -939.40 & -3.48 \\
\hline Bare Surfaces & -1812.06 & -19.64 & -555.84 & -7.49 & -97.74 & -1.42 & 48.33 & 0.71 \\
\hline $\begin{array}{l}\text { Highlands/ } \\
\text { Rock Outcrop }\end{array}$ & -586.26 & -6.30 & -458.10 & -5.25 & -331.74 & -4.01 & -232.29 & -2.93 \\
\hline
\end{tabular}


depict the pattern of changes expected in the area when all factors remain constant. Gombe metropolis will continue to experience growth as it has been in the historical times. This phenomenon will continue to have both ecological and socio-economic consequences on the environment as well as the people living in the area.

The implications of continuous urban growth in Gombe metropolis cannot be different from what obtains in larger urban centers of Nigeria and the other developing countries of the world. As the metropolis is expected to grow, there is the need to checkmate the vices associated with improper planning of urban centers. Some of the negative implications of urbanization include among others; slump creation, increase in crime, inadequate provision of social amenities and inadequate housing. Furthermore, urban growth adds to overall travel costs owing to increase in commuting to work place and residential locations due to the spreading out of development [3] [4] [12]. Therefore in order to avoid this future catastrophe, the city authorities and the government of Gombe State should put in place the necessary mechanism that will help in averting the occurrence of negative consequences. This can be done by developing a master plan that will incorporate the areas that will be affected by the predicted expansion and strict development control measures.

\section{Conclusion}

The study analyses the present and the future growth trend of Gombe metropolis. The results show that the metropolis has been experiencing rapid growth since its declaration as the capital city of Gombe State in 1996. This phenomenal growth is in line with the findings of [1], [2] and [8] which showed similar trend. Such rapid growth will continue to have both ecological and socio-economic consequences on the environment as well as the people living in the area. The problems of flooding, soil erosion, inadequate housing and slumps, and lack of other infrastructure facilities will likely increase in dimension. In order to ensure that urbanization contributes to sustainable growth and higher standard of living and to avoid the negative implications of urbanization witnessed in many cities of the developing world, global best practice should be adopted. Therefore, the study recommends that concerted efforts should be made to address the major challenges associated with urban growth and proper management and planning of future development of Gombe metropolis should be in line with global best practices. Specific environmental concerns should merit special attention within a framework of a larger plan in addressing the challenges.

\section{References}

[1] Onibokun, A. and Faniran, A. (1995) Urbanization and Urban Problems in Nigeria In: Urban Research in Nigeria [Online]. Institut français de recherche en Afrique, Ibadan. http://books.openedition.org/ifra/544 https://doi.org/10.4000/books.ifra.544

[2] Opoko, A.P. and Oluwatayo, A. (2014) Trends in Urbanisation: Implication for 
Planning and Low-Income Housing Delivery in Lagos, Nigeria. Architecture Research, 4, 15-26.

[3] Almeida, C.M., Gleriani, J.M., Castejon, E.F. and Soares-Filho, B.S. (2008) Using Neural Networks and Cellular Automata for Modeling Intra-Urban Land-Use Dynamics. International Journal of Geographical Information Science, 22, 943-963. https://doi.org/10.1080/13658810701731168

[4] Herold, M., Goldstein, N.C. and Clarke, K.C. (2003) The Spatiotemporal Form of Urban Growth: Measurement, Analysis and Modeling. Remote Sensing of Environment, 86, 286-302. https://doi.org/10.1016/S0034-4257(03)00075-0

[5] Otto, G. (2008) Urbanization in Nigeria: Implications for Socio-Economic Development. Journal of Research in National Development, 6. http://www.transcampus.org/JORINDV6Dec2008/JournalsV6NO2Dec200821.html

[6] Freire, M.E., Lall, S. and Leipziger, D. (2014) Africa's Urbanization: Challenges and Opportunities. The Growth Dialogue, Working Paper No. 7.

[7] African Development Bank (2012) Championing Inclusive Growth across Africa. http://www.afdb.org/en/blogs/afdb-championing-inclusive-growth-across-africa/po st/urbanization-in-africa-10143/

[8] Henderson, J.V., Roberts, M. and Storeygard, A. (2013) Is Urbanization in Sub-Saharan Africa Different? Policy Research Working Paper 6481. World Bank, Washington DC.

[9] Oguntoyinbo, J.S. (1983) Climate. In: Oguntoyinbo, J.S., Areola, O.O. and Filani, M., Eds., A geography of Nigerian Development, 2nd Edition, Heinemann Educational Books, Ibadan.

[10] Lu, D., Mausel, P., Brondízio, E. and Moran, E. (2004) Change Detection Techniques. International Journal of Remote Sensing, 25, 2365-2401. https://doi.org/10.1080/0143116031000139863

[11] Pu, R., Gong, P., Tian, Y., Miao, X., Carruthers, R.I. and Anderson, G.L. (2008). Using Classification and NDVI Differencing Methods for Monitoring Sparse Vegetation Coverage: A Case Study of Saltcedar in Nevada, USA. International Journal of Remote Sensing, 29, 3987-4011. https://doi.org/10.1080/01431160801908095

[12] Wilson, E.H., Hurd, J.D., Civco, D.L., Prisloe, M.P. and Arnold, C. (2003) Development of a Geospatial Model to Quantify, Describe and Map Urban Growth. Remote Sensing of Environment, 86, 275-285. https://doi.org/10.1016/S0034-4257(03)00074-9 